\title{
Construction of a Populus tremuloides Michx. BAC library
}

\author{
By M. Fladung ${ }^{1)}$, H. Kaufmann ${ }^{2)}$, T. Markussen and H. Hoenicka \\ Federal Research Centre for Forestry and Forest Products, Institute for Forest Genetics and Forest Tree Breeding, \\ Sieker Landstr. 2, D-22927 Grosshansdorf, Germany
}

(Received 13 $3^{\text {th }}$ November 2006)

\begin{abstract}
We have constructed an aspen (Populus tremuloides Michx., line Turesson141) BAC library containing 55,296 clones in total. A random sampling of $86 \mathrm{BAC}$ clones indicated an average insert size of $76 \mathrm{~kb}$ with a range of 20 to $160 \mathrm{~kb}$. Twelve percent of the BAC clones in the library have an insert size larger than $100 \mathrm{~kb}$. Based on an estimated genome size for Populus of 500 Mbp, library coverage is about 8 haploid genome equivalents. This library will be screened using AFLP marker identified before co-segregating with gender in a $P$. tremula $\mathrm{x} P$. tremuloides progeny, where Turesson141 was the male parent.
\end{abstract}

Key words: Bacterial Artificial Chromosome, Populus, genome size, aspen.

\section{Introduction}

Poplar is one of the world's most important tree species. Their rapid growth and capacity to supply a broad range of wood products has led to their widespread cultivation in Europe and North America (DICKMAN and STUART, 1983; STETTLER et al., 1996). In addition to their commercial value, poplars and hybrid poplars are ecologically important as they are effective in the control of nutrients and toxic compounds found in agricultural liquid waste and landfill effluents (BRAATNE, 1999).

The genus Populus serves as model tree species for gene technological studies and genomic research for several reasons: (1) Populus trichocarpa is the only tree species which has been completely sequenced up to now (http://www.ornl.gov/sci/ipgc/), (2) The genome size of poplar with approximately $500 \mathrm{Mbp}$ is small. This is similar in size to the rice genome and only four times larger than the genome of Arabidopsis, yet 40 times smaller than the genome of pines (3). Further, there are many genomic efforts in this genus including availability of a high number of expressed sequence tag (EST-) data (BHALERAO et al., 2003).

However, as for most of the forest tree species improvement in poplar is hampered by tree-specific features like long juvenility phases and slow growth. Despite of successful sequencing in one poplar species,

\footnotetext{
1) Corresponding author: Matthias Fladung, Federal Research Centre for Forestry and Forest Products, Institute for Forest Genetics and Forest Tree Breeding, Sieker Landstr. 2, D-22927 Grosshansdorf. Fax: +49-4102-696200, Email: mfladung@uni-hamburg.de.

2) Present address: Leibniz-University, Institute of Floriculture and Tree Nursery Science, Herrenhäuser Str. 2, D-30419 Hanover, Germany.
}

very few knowledge is available about tree genetics due to the lack of inbred lines required for intensive genetic studies. Nowadays, novel molecular breeding tools have been developed allowing the creation of and screening for novel poplar genotypes.

During the last decade several genomic maps have been published for different poplar species using RAPD-, AFLP-, EST-, and SSR marker (for overview: CERVERA et al., 2004, e.g. P. trichocarpa (CERVERA et al., 2001), $P$. alba (Yin et al., 2001), P. nigra (CERVERA et al., 2001), $P$. deltoides (YIN et al., 2002), and P. tremula $\times$ P. tremuloides, $P$. tremula x tremula (MEYER et al., pers. communication). On basis of these maps a physical mapping and cloning of genes associated with important developmental and/or wood traits would be feasible if a BAC(Bacterial Artificial Chromosome) library is available.

For woody plants the construction of BAC libraries was reported mainly for fruit trees and horticultural crops, like coffee (NoIR et al., 2004), apple (VINATZER et al., 1998; PAтосCHI et al., 1999; Xu et al., 2001), peach (WANG et al., 2001), apricot (VILANOVA et al.. 2003), grape (Tomkins et al., 2001) and rose (KAUFMANN et al., 2003). But also for forest trees BAC libraries have been constructed for Eucalyptus (GRATTAPAGLIA, 2004) and Liroidendron tulipifera (http://www.greenbac.org/index. html). Two BAC libraries have been constructed for $P$. trichocarpa in order to characterise and isolate the MXC3 locus a major gene for resistance to poplar leaf rust (STIRLING et al., 2001) as well as the R-locus for resistance against Melampsora larici-populina causing leaf rust (FAIVRE RAMPANT et al., 2006). The BAC library from the $P$. trichocarpa clone 383-2499 (Nisqually-1) was used to sequence the whole poplar genome. In frame of the EU-Network of Excellence "EvolTree" (www.evoltree.org) it is planned to construct a BAC library from Quercus but also further ones from Populus.

In this study we report the construction and characterisation of a BAC library from aspen-Populus tremuloides. To the best of our knowledge, the $P$. tremuloides (aspen) BAC library reported here is the first largeinsert DNA library so far constructed for this species, and the third reported for the genus Populus.

\section{Material and Methods}

\section{Plant material}

Leaves of a single, approximately 40 years-old Populus tremuloides Michx. tree (clone Turesson141) growing in the 'Arboretum Tannenhöft' of the Institute of Forest Genetics and Forest Tree Breeding, Grosshansdorf, Ger- 
many, were used. Leaf material of different ages (young [starting to unfold] and mature [up to four weeks old]) was harvested, kept for two days in the dark, frozen in liquid nitrogen and stored at $-80^{\circ} \mathrm{C}$. For the isolation of nuclei suitable for BAC cloning frozen leaf material was ground under liquid nitrogen using the Retsch Bead Mill (Retsch, Duesseldorf, Germany) or mortar and pestle.

\section{BAC library construction}

The aspen BAC library was constructed following the protocol described by KAUFMANN et al. (2003). However, each working step had to be optimised for $P$. tremuloides as described in the results section. All other molecular procedures not citied separately were done as described in SAMBRock et al. (1989).

The isolation and lysis of aspen nuclei as well as the PMSF (Phenylmethylsulphonylfluoride) treatment was performed as described in KAUFMANN et al. (2003) with some modifications (see results). For partial restriction HindIII concentrations between 0.8 and $50 \mathrm{U}$ per agarose plug were tested to obtain DNA fragments in a size range of $100-350 \mathrm{~kb}$. Restricted DNA was separated using the pulsed-field gel electrophoresis CHEF-DRIIsystem (Bio-Rad, Germany) and DNA of the appropriate size was cut out of the gel and electroeluted (STRONG et al., 1997).

Eluted DNA was dialysed and ligated into the BAC vector pBeloBACII (KIM et al., 1996). The plasmid has a size of $7.4 \mathrm{~kb}$ and carries a chloramphenicol-resistance gene. Sequence of the vector as well as restriction map are available under http://www.sanger.ac.uk/Teams/ Team53/psub/sequences/pbelobac.shtml and http://www. sanger.ac.uk/Teams/Team53/psub/sequences/pbelobac. pdf, respectively. The plasmid was restricted with HindIII, dephosphorylated and tested for cloning ability as described by PETERson et al. (2000).

Following heat inactivation and dialysis the ligation mixtures were transformed in electrocompetent $E$. coli DH10B cells (Life technologies) using an E. coli Pulser transformation apparatus (BioRad, Germany).

\section{Characterisation of the BAC library}

The ligation mixtures showing a satisfactory transformation rate and a high proportion of white colonies were tested more in detail.

BAC-DNA was prepared by a standard alkaline lysis method from 2-ml overnight cultures in TB with antibiotic and resuspended in $30 \mu \mathrm{l}$ of TE. Five $\mu \mathrm{l}$ of BACMini-DNA were digested with $N o t \mathrm{I}$ in a volume of $20 \mu \mathrm{l}$ at $37^{\circ} \mathrm{C}$ for $2 \mathrm{hrs}$. For pulsed-field gel electrophoresis, samples were loaded on a $1 \%$ TAE agarose gel and electrophorised with 5 to 15 sec pulse time for $20 \mathrm{~h}$ with field strength of $4.5 \mathrm{~V} / \mathrm{cm}$ at $14^{\circ} \mathrm{C}$.

\section{Results and Discussion}

Optimisation of nucleus preparation, restriction, and pulsed-field gel electrophoresis

The protocol for construction of a rose BAC library (KAUFMANN et al., 2003) was modified to optimize the construction of an aspen BAC library. Rose and aspen have a similar genome size which is about four times larger than Arabidopsis (about $500 \mathrm{Mbp}$ or a $1 \mathrm{C}$ value of about $0.5 \mathrm{pg}$ (YoKOYA et al., 2000), http://www.ornl. gov/sci/ipg /). In both genera DNA isolation might be hampered by presence of polyphenolic compounds or polysaccharides in leaves.

For nuclei and subsequent DNA isolation, in total, nine different preparations were done. Out of these, five preparations yielded in high-quality DNA which could be used for cloning experiments. Comparative grinding under liquid nitrogen using the Retsch Bead Mill and traditional mortar and pestle revealed no differences in nuclei yield, but later on a higher cloning success was obtained when using mortar and pestle.

To identify leaf age for optimal nuclei preparation young (starting to unfold) and mature (up to four weeks old) leaves were harvested. Slight or no differences were found with respect to DNA quality and purity. On the other hand, composition of lysis buffer is crucial for nuclei quality. The lysis buffer according to PETERSON et al. (2000) was slightly modified: concentrations of PVP40 and 2-mercaptoethanol were increased to $5 \%$ and $0.5 \%$, respectively, to avoid oxidative processes which affect the quality of DNA. Increase of the Triton $\mathrm{X}$ 100 concentration to $1 \%$ resulted in a more effective lysis of chloroplasts, thus, a higher purity of the nuclei was achieved.

Optimal HindIII concentration for partial restriction to obtain DNA fragments with sizes between 100 and $350 \mathrm{~kb}$ was found between 4 to $40 \mathrm{U}$ per agarose plug with an incubation time of 30 minutes at $37^{\circ} \mathrm{C}$. Three different pulsed-field gel electrophoresis conditions were tested. First, as described for construction of the rose BAC library (KAUFMANN et al., 2003), a two-phase electrophoresis with 60 to $90 \mathrm{sec}$ pulse time for 5 hours and subsequent $4 \mathrm{sec}$ for 16 hours was tested. By using these electrophoresis conditions BAC clones with sizes about $50 \mathrm{~kb}$ were obtained. A three-phase electrophoresis with 60 to $90 \mathrm{sec}$ pulse time for 8 hours, $4 \mathrm{sec}$ for 20 hours, and finally $4.5 \mathrm{sec}$ for 16 hours (Allouis et al., 2001) yielded clones with sizes between 50 and $70 \mathrm{~kb}$. Third, a one-phase electrophoresis with 1 to $40 \mathrm{sec}$ pulse time for 24 hours revealed inserts between 80 and $100 \mathrm{~kb}$.

A further significant point is loading density of the pulsed-field gel. It is important to obtain a minimal density of $0.5 \mu \mathrm{g} / \mu \mathrm{l}$ of DNA in the eluate but without overloading the gel, the latter leading to co-migration of small DNA fragments. To slightly increase loading density the thickness of the loading slot was increased from the standard 1.5 to $4.5 \mathrm{~mm}$. The eluate used in the successful cloning experiment had a concentration of $3 \mathrm{ng} / \mu \mathrm{l}$.

Different conditions for ligation and transformations were tested to gain optimal number of clones and largest insertions (Table 1). For ligation amount of DNA and the vector, but as well also different ligation buffers (Invitrogen, Germany, and NBI Fermentas, Lithuania) were tested. The optimal conditions for ligation revealed to be $15 \mathrm{ng}$ vectors per $100 \mu \mathrm{l}$ in combination with as high as possible concentration of DNA in PEG-free 
buffer. In the subsequent desalting procedure dialysis against $0.5 \times$ TE (KAUFMANN et al., 2003) was found to be more effective than 10\% PEG 8000 (PETERSON et al., 2000). Finally, addition of tRNA as carrier (ZHU et al., 1999) increased the transformation efficiency.

\section{Protocol for the construction of an aspen BAC library}

Four grams of frozen leaf material were grinded under liquid nitrogen and resuspended in $40 \mathrm{ml}$ lysis buffer (PETERson et al., 2000) supplemented with 5\% PVP40, $1 \%$ Triton X100 as well as 0,5\% 2-mercaptoethanol. Following filtration through Miracloth (Calbiochem, San Diego, USA) and various washing steps using lysis buffer the nuclei were transferred to $1 \mathrm{ml}$ lysis buffer without 2-mercaptoethanol mixed with $1 \mathrm{ml}$ of $1.2 \%$ Low Melting Point agarose (Seaplaque FMC, USA) and moulded to small plugs.

The plugs were incubated in 0,5M EDTA pH 9.0, 1\% sodiumlaurylsarcosine, $2 \%$ PVP 40 and $0.4 \mathrm{mg} / \mathrm{ml}$ proteinase $\mathrm{K}$ for 72 hours at $50^{\circ} \mathrm{C}$ with two buffer changes. Following lysis, the blocks were washed five times for

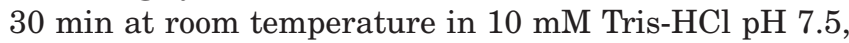
$10 \mathrm{mM}$ EDTA, 2\% PVP 40 and $0.5 \mathrm{mM}$ PMSF. Before restriction the plugs were chopped into small pieces and equilibrated for $90 \mathrm{~min}$ in React 2-buffer plus $4 \mathrm{mM}$ spermidine-HCl and $100 \mu \mathrm{g} / \mathrm{ml}$ BSA. Following $15 \mathrm{~min}$ incubation in React 2-buffer (Invitrogen, Germany),
$4 \mathrm{mM}$ spermidine-HCl, $100 \mu \mathrm{g} / \mathrm{ml} \mathrm{BSA}$ and $40 \mathrm{U}$ HindIII on ice restriction was performed at $37^{\circ} \mathrm{C}$ for $30 \mathrm{~min}$. Restriction was stopped by adding $50 \mathrm{mM}$ EDTA.

Partially restricted DNA was separated through pulsed-field gel electrophoresis (CHEF-DRII-System) on a $1 \%$ preparative LMP agarose gel in $1 \times \mathrm{TAE}$ using the following parameter: $1-40$ sec pulse time, $3,5 \mathrm{~V} / \mathrm{cm}$, $1200,10^{\circ} \mathrm{C}$ for 20 hours. Slices of agarose containing DNA of sizes from 80 to $180 \mathrm{~kb}$, from 180 to $250 \mathrm{~kb}$ and from 250 to $350 \mathrm{~kb}$ were excised and electro-eluted following the protocol by STRONG et al. (1997). Ligation with HindIII digested pBeloBACII-vector was performed in a final volume of $170 \mu \mathrm{l}$ with $7.5 \mathrm{U}$ T4-DNALigase (Life Technologies), $450 \mathrm{ng}$ eluted DNA (fraction 250 to $350 \mathrm{kB}$ ) and $25 \mathrm{ng}$ vector. Following heat inactivation of ligase and desalting $2 \mu \mathrm{l}$ of ligation solution were mixed with $40 \mu \mathrm{l}$ competent $E$. coli DH10B cells (Invitrogen, Germany) using an E. coli pulser (Biorad, Germany) at $11 \mathrm{kV} / \mathrm{cm}$ (KAUFMANN et al., 2003). After $45 \mathrm{~min}$ of recovery at $37^{\circ} \mathrm{C}$ in $0.5 \mathrm{ml}$ SOC-medium transformed $E$. coli cells were plated on LB-agar containing IPTG, X-gal (SAMBRoOK et al., 1989) and $12.5 \mu \mathrm{g} / \mathrm{ml}$ chloramphenicole and incubated at $37^{\circ} \mathrm{C}$ for 20 hours. Transformation rate was about 800 recombinant (white) clones per $\mu$ l ligation solution. In total 55,296 clones were picked and stored in one hundred forty-four 384-well microtiter plates.

Table 1. - Influence of different parameters on ligation and transformation.

\begin{tabular}{|c|c|}
\hline & $\begin{array}{l}\text { Efficiency of } \\
\text { transformation }\end{array}$ \\
\hline $\begin{array}{l}\text { Standard ligation, volume }=100 \mu l \text { (Kaufmann et al. 2003) } \\
\text { 50ng DNA, } 20 \text { ng vector, 5xligase buffer without PEG, 5U } \\
\text { ligase }\end{array}$ & $100 \%$ \\
\hline 50ng DNA, 20 ng vector, 5xligase buffer with PEG, 5U ligase & $18 \%$ \\
\hline $\begin{array}{l}\text { DNA-dilution 1:1 ( } 25 \text { ng DNA/100 } \mu 1), 20 \text { ng vector, 5xligase } \\
\text { buffer without PEG, 5U ligase }\end{array}$ & $46 \%$ \\
\hline $\begin{array}{l}\text { DNA-dilution 2:1 (37 ng DNA/100 } \mu 1), 20 \text { ng vector, 5xligase } \\
\text { buffer without PEG, 5U ligase }\end{array}$ & $73 \%$ \\
\hline $\begin{array}{l}\text { 50ng DNA, } 30 \mathrm{ng} \text { vector, } 5 x \text { ligase buffer without PEG, } 5 \mathrm{U} \\
\text { ligase }\end{array}$ & $70 \%$ \\
\hline $\begin{array}{l}\text { 50ng DNA, } 15 \text { ng vector, 5xligase buffer without PEG, } 5 \mathrm{U} \\
\text { ligase }\end{array}$ & $200 \%$ \\
\hline $\begin{array}{l}\text { Standard transformation (Petersen et al. 2000) } \\
11 \mathrm{kV} / \mathrm{cm} \text {, pre-treatment: dialysis } 10 \% \mathrm{PEG} \text {, no carrier }\end{array}$ & $100 \%$ \\
\hline $11 \mathrm{kV} / \mathrm{cm}$, pre-treatment: dialysis $0,5 \times T E$, no carrier & $137 \%$ \\
\hline $\begin{array}{l}11 \mathrm{kV} / \mathrm{cm} \text {, pre-treatment: dialysis } 0,5 \times \mathrm{xE} \text {, addition of } 1 \mu \mathrm{g} \\
\text { tRNA as carrier }\end{array}$ & $200 \%$ \\
\hline
\end{tabular}

* modifications underlined. 


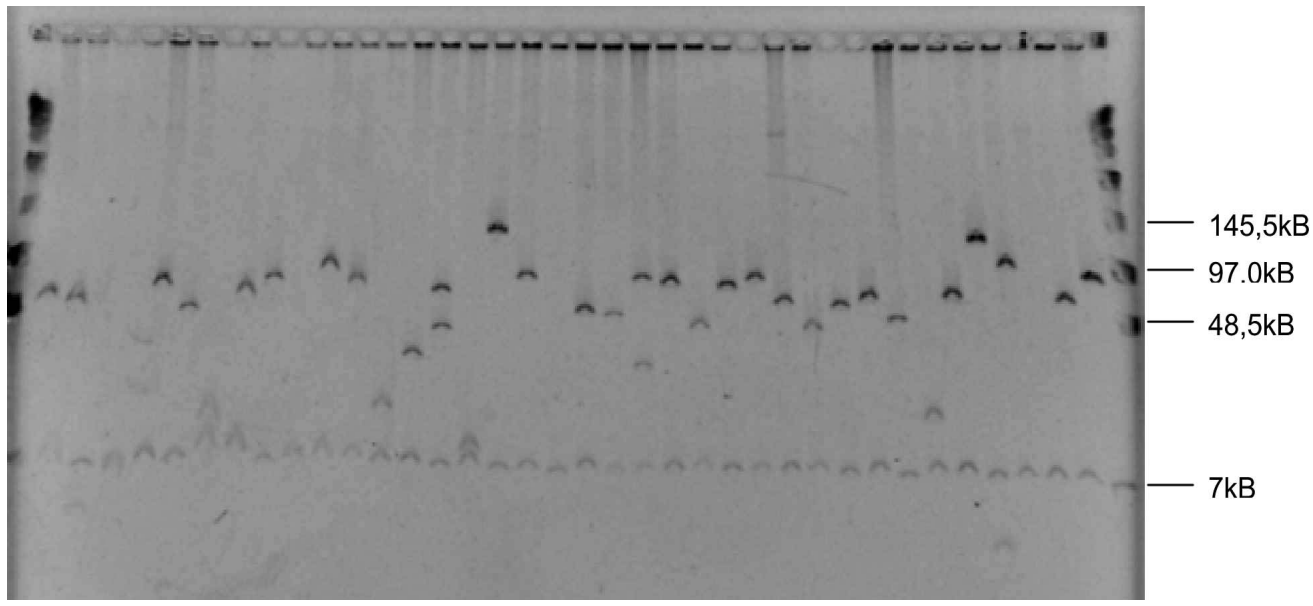

Figure 1. - Pulse-field gel electrophoresis of NotI digested aspen BAC clones. Inverted image of an ethidium bromide stained gel showing the inserts of 38 clones.

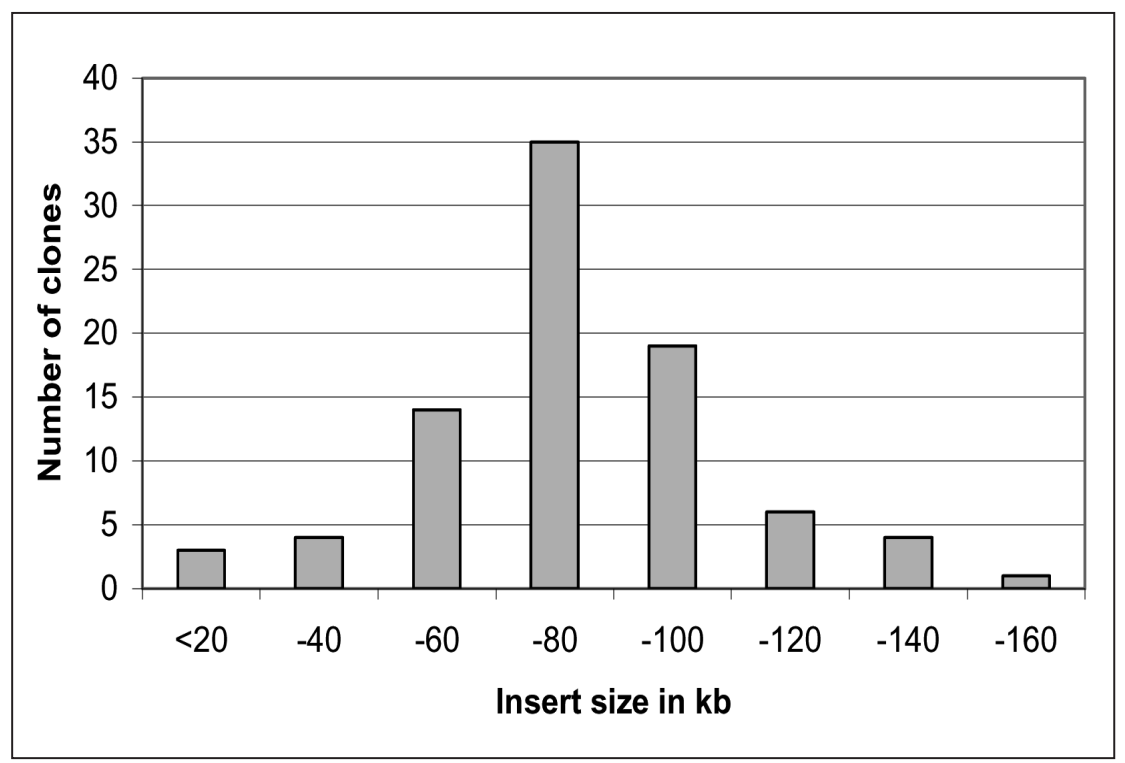

Figure 2. - Insert size distribution of clones in the aspen BAC library. 86 BAC clones were randomly selected and digested with NotI. The fragment sizes were determined by pulse-field gel electrophoresis and plotted against frequency of occurrence.

\section{Characterisation of the aspen BAC library}

To determine the insert-size distribution and average insert size of the aspen BAC library, DNA was isolated from 90 randomly selected clones, digested with Not I and separated by pulse-field gel electrophoresis (Fig. 1). Four clones had no insert (corresponding to $4.4 \%$ ), while the residual contained inserts ranging from 20 to $160 \mathrm{~kb}$ in size (Fig. 2). Average size is $76 \mathrm{~kb}$, and twelve percent of the BAC clones in the library have an insert size higher than $100 \mathrm{~kb}$.

The percentage of clones in the library that contained organelle DNA was determined by less than 5\%. Most of these clones had chloroplast sequences, but only less than $0.1 \%$ carries inserts of mitochondrial origin. Based on the haploid genome size of about $0.5 \mathrm{pg}$ correspond- ing to $500 \mathrm{Mbp}$ (http://www.ornl.gov/sci/ipgc/), this library is estimated to contain 8 genome equivalents. Therefore, the probability of recovering any given sequence of the aspen genomic DNA from this library is higher than 99\% (ClaRKE and CARBON, 1976).

The library reported here is well suited for many applications in forest tree genome research. In combination with the $P$. tremuloides genomic map, a map-based cloning approach can be initiated to investigate molecular markers for gender which has already been mapped (Markussen et al., Silvae Genetica, in press). Considering the high number of genomic maps available for this genus as well as the genome sequence of $P$. trichocarpa ( $h t t$ p://www.ornl.gov/sci/ipgc/) which has been generated from a BAC library a comparative physical mapping approach is now feasible in the genus Populus. 


\section{Acknowledgements}

This study was supported by the German Research Foundation (FL263/2-1 and FL263/2-2). We wish to thank O. Nowitzki and A. Tusch for excellent technical assistance.

\section{References}

Allouis, S., X. QI, M. D. Gale and K. M. Devos (2001): Construction of a BAC library of pearl millet, Pennisetum glaucum. Theor. Appl. Genet. 102: 1200-1205.

BhaleraO, R., O. Nilsson and G. Sandberg (2003): Out of the woods: forest biotechnology enters the genomic era. Curr. Opin. Biotechnol. 14: 206-213.

BRAATNE, J. H. (1999): Biological aspects of hybrid poplar cultivation on floodplains in western North America. Prepared for U.S. EPA (Region 10), Seattle, WA, Document No. 910-R-99-002.

Cervera, M. T., M. M. Sewell, P. Faivre-Rampant, V. Storme and W. BoerJan (2004): Genome mapping in Populus. In: Kumar, S., Fladung, M. (Eds) Molecular Genetics and Breeding of Forest Trees. The Haworth Press, Binghamton, 387-410.

Cervera, M. T., V. Storme, B. Ivens, J. Gusmão, B. H. Liu, V. Hostyn, J. VAn Slycken, M. Van Montagu and W. BoerJan (2001): Dense genetic linkage maps of three Populus species (Populus deltoides, $P$. nigra and P. trichocarpa) based on AFLP and microsatellite markers. Genetics 158: 787-809.

ClaRke, L. and J. CARBON (1976): A colony bank containing synthetic Col EI hybrid plasmids representative of the entire $E$. coli genome. Cell 9: 91-99.

Dickman, D. I. and K. W. StuART (1983): The Culture of Poplars in Eastern North America. Department of Forestry Publications, Michigan State University, East Lansing, Michigan.

Faivre Rampant, P., L. Bataille, A. Bresson, N. Boudet, B. Chalhoub, V. Jorge, A. Dowkiw, V. Guerin, J. P. Masle, M. Villar and C. Bastien (2006): Genetic and Physical mapping of a genetic factor involving in partial rust resistance in Populus trichocarpa. IV International Poplar Symposium, Nanjing, China.

GRATTAPAGLIA, D. (2004): Integrating genomics into Eucalyptus breeding. Genet. Mol. Res. 3: 369-379.

Kaufmann, H., L. Mattiesch, H. LöRZ and T. Debener (2003): Construction of a BAC library of Rosa rugosa Thunb. And assembly of a contig spanning $R d r 1$, a gene that confers resistance to blackspot. Mol. Genet. Genomics 268: 666-674.

Kim, U. J., B. W. BirRen, T. Slepak, V. Mancino, D. BoySEN, H. L. Kang, M. I. Simon and H. Shizuya (1996): Construction and characterization of a human bacterial artificial chromosome library. Genomics 34: 213-218.

Noir, S., S. Patheyron, M. C. Combes, P. Lashermes and B. ChalHoub (2004): Construction and characterisation of a BAC library for genome analysis of the allotetraploid coffee species (Coffea arabica L.). Theor. Appl. Genet. 109: 225-230.

Patocchi, A., B. A. Vinatzer, L. Gianfrancesci, S. Tartarini, H. B. Zhang, S. SAnsavini and C. Gessler (1999): Construction of a 550-kb BAC contig spanning the genomic region containing the apple scab resistance gene Vf. Mol. Genet. Genomics 262: 884-891.
Peterson, D. G., J. P. Tomkins, D. A. Frisch, R. A. Wing and A. H. PATERSON (2000): Construction of plant bacterial artificial chromosome (BAC) libraries: an illustrated guide. JAG 5: www.ncgr.org/research/jag.

SAmbrooK, J., E. F. Fritsch and T. MANiatis (1989): Molecular cloning: a laboratory manual, $2^{\text {nd }}$ Edn, Cold Spring Harbour Laboratory Press, New York.

Stettler, R. F., H. D. Bradshaw, P. E. Heilman and T. M. HinCKLEY (1996): Biology of Populus: Implications for management and conservation. National Research Council of Canada, Ottawa.

Stirling, B., G. Newcombe, J. VRebalov, I. Bosdet and H. D. BRADSHAW (2001): Suppressed recombination around the MXC3 locus, a major gene for resistance to poplar leaf rust. Theor. Appl. Genet. 103: 1129-1137.

Strong, S. J., Y. Ohta, G. W. Litman and C. T. Amemiya (1997): Marked improvement of PAC and BAC cloning is achieved using electroelution of pulsed-field gel-separated partial digests of genomic DNA. Nucleic Acids Res. 25: 3959-3961.

Tomkins, J. P., D. G. Peterson, T. J. Yang, D. Main, E. F. Ablett, R. J. Henry, L. S. Lee, T. A. Holton, D. Waters and R. A. WING (2001): Grape (Vitis vinifera L.) BAC library construction, preliminary STC analysis, and identification of clones associated with flavonoid and stilbene biosynthesis. Amer. J. Enomol. Viticult. 52: 287-291.

Vilanova, S., C. Romero, D. Abernathy, A. G. Авbott, L. Burgos, G. Llacer and M. L. Badenes (2003): Construction and application of a bacterial artificial chromosome (BAC) library of Prunus armeniaca L. for the identification of clones linked to the self-incompatibility locus. Mol. Genet. Genomics 269: 685-691.

VinAtZer, B. A., H. B. ZhANG and S. SANSAVINI (1998): Construction and characterization of a bacterial artificial chromosome library of apple. Theor. Appl. Genet. 97: 1183-1190.

Wang, W., W. Zhai, M. Luo, G. Jiang, X. Chen, X. Li, R. A. Wing and L. ZHU (2001): Chromosome landing at the bacterial blight resistance gene Xa4 locus using a deep coverage rice BAC library. Mol. Genet. Genomics 265: $118-125$.

Xu, M. L., J. Q. Song, Z. K. Cheng, J. M. JiAng and S. S. KoRBAN (2001): A bacterial artificial chromosome (BAC) library of Malus floribunda 821 and contig construction for positional cloning of the apple scab resistance gene Vf. Genome 44: 1104-1113.

Yin, T. M., M. R. Huang, M. X. Wang, L. H. Zhu, Z. B. ZENG and R. L. WU (2001): Preliminary interspecific genetic maps of the Populus genome constructed from RAPD markers. Genome 44: 602-609.

Yin, T. M., X. Y. Zhang, M. R. Huang, M. X. Wang, Q. Zhuge, S. M. Tu, L. H. Zhu and R. L. Wu (2002): Molecular linkage maps of the Populus genome. Genome 45: 541-555.

Yokoya, K., A. V. Roberts, J. Mottley, R. Lewis and P. E. BRANDHAM (2000): Nuclear DNA amounts in roses. Ann. Bot. 85: $557-561$.

Zhu, H. and R. A. DeAN (1999): A novel method for increasing the transformation efficiency of $E$. coli application for bacterial artificial chromosome library construction. Nucleic Acids Res. 27: 910-912. 